section those of archæology. In connexion with the opening ceremonies honorary degrees were conferred by the University of Toronto upon Dr. C. G. Abbott, secretary of the Smithsonian Institution, Washington, Mr. J. B. O'Brian, chairman of the Board of Trustees, Mrs. H. D. Warren, vice-chairman, and Mr. Sigmund Samuel, member of the Board.

\section{Microchemical Club}

A Mrcrochemrad Club is being formed by a number of scientific workers interested in the use and improvement of microchemical methods, for the purpose of developing interest in the science, pooling ideas, and subscribing to certain journals. The new technique of microchemistry, with which the names of Profs. Behrens, Emich and Pregl are particularly associated, has rapidly established itself as a valuable tool for research, and recognition of the importance of microchemistry led to the award of the Nobel prize to Prof. Pregl in 1923. The methods have been of inestimable value in noted researches in many fields of science. While microchemical methods are widely used in universities, research institutes and industrial laboratories on the Continent and in the United States, Great Britain has hitherto lagged behind. The importance of the new methods is now beginning to be realised in Great Britain, and the Microchemical Club hopes to foster the development of this new technique in pure chemistry, metallurgy, geology, biochemistry, medical science and other branches of scientific study. The secretary of the Club, Dr. M. Healey, Wellcome Physiological Research Laboratory, Beckenham, Kent, will be pleased to answer inquiries from anyone who is interested.

\section{Relics of the Barents Expedition}

IT is reported in the Moscow Daily News that an expedition, organised by the Arctic Institute of the U.S.S.R. which has recently returned to Leningrad, has discovered relics of the Barents expedition which perished in 1597. William Barents was a Dutch navigator born about the middle of the sixteenth century. In 1594 he left Amsterdam with two ships to search for a north-east passage to eastern Asia, but failed. He commanded another expedition of seven ships in the following year, but was too late to find open water. His third journey resulted in catastrophe. After rounding the north of Novaya Zemlya in 1596, Barents' vessel was beset by ice and compelled to winter in the north. It was the first winter ever experienced by Europeans in polar regions. Barents' ship was not released until 1597. His party left in two open boats on June 13, and most of its members escaped. Barents himself died on June 30 , 1597, with four members of his crew. The expedition of the Arctic Institute of the U.S.S.R. discovered on August 18 last some relies of the hut in which Barents wintered on the north-east extremity of Cape Spora Novolsk. These relics will be preserved in the Museum of the Arctic Institute in Leningrad.

\section{Map of Columbus}

No authentic map of Columbus was known until Prof. P. Kahle in 1929 found among a number of old charts in the Seraglio at Istanbul a coloured Turkish map of the Atlantic with its islands and coasts. One of the several legends on the map shows it to be the work of Piri Re'is in 1513. Piri Re'is is known as the writer of an important work on the Mediterranean published in 1521. Prof. Kahle has prepared an account of this map, with a reproduction (Geog. Rev., October 1933). It is clearly only the western part of an original world map. On the extant part, there is a list of sources which includes reference to a map drawn by Columbus. Prof. Kahle adduces evidence in favour of this map having been drawn by Columbus during the earlier part of his third voyage, since it incorporates his discoveries up to that time but not his later experiences on the third voyage or discoveries on the fourth voyage. It is known that during his third voyage Columbus sent to Spain the only map of his about the existence of which there is no doubt. It was evidently a copy of this map, of which several are known to have been made, which fell into the hands of Piri Re'is in 1501. It is noteworthy that the list of sources on the map contains no reference to the reputed map and letters of Toscanelli.

\section{Social and Economic Problems}

Referring to the leading article on "Social and Economic Problems" in Nature of October 28, Dr. J. F. S. Ross, principal of Wigan and District Mining and Technical College, writes: "Surely what is wanted is not the multiplication of ungainly-and probably bored-committees, but the stimulation of larger numbers of scientists to the active study of social and economic questions, so that scientific method may be utilised towards the solution of the desperately urgent problems that politicians and professional economists seem unable to solve, or even in many cases to recognise. Not a proliferation of committees is needed, but more unbiassed soientific research into the realities of politics, sociology and economics. For such work the training, knowledge and outlook of physicists, biologists and scientific engineers is an invaluable basis, and the lack of such a basis must be held responsible for the futility and unreality of much political and economic discussion."

\section{Mr. Theodore C. Rigg}

Mr. Theodore C. RIgG has been appointed director of the Cawthron Institute, Nelson, New Zealand, on the retirement of Prof. T. H. Easterfield. Mr. Rigg was an 1851 Exhibition scholar in 1912 and carried out post-graduate research at the School of Agriculture, Cambridge, until 1914, returning after the War to study at Rothamsted. He was appointed agricultural chemist at the Cawthron Institute in 1919, and has since held positions as head of the Agricultural Department and as assistant director. $\mathrm{He}$ has been in charge of the Mineral Content of Pastures Investigation of the Nelson Territory since 1928, and has directed the Reconnaissance Soil Survey of the North Island. His work on animal nutrition, and particularly on the cause and prevention of bush sickness, is well known. 